\title{
PENGARUH Sansevieria spp. TERHADAP PENURUNAN TINGKAT RADIASI ELEKTROMAGNETIK DI LABORATORIUM JURUSAN KESEHATAN LINGKUNGAN PURWOKERTO TAHUN 2016
}

\author{
Retno Printis Mulyani' ${ }^{1)}$, Sugeng Abdullah²), Yulianto ${ }^{3)}$ \\ Jurusan Kesehatan Lingkungan, Politeknik Kesehatan Kemenkes Semarang, \\ Jl. Raya Baturaden KM 12 Purwokerto, Indonesia
}

\begin{abstract}
Abstrak
Radiasi elektromagnetik yang dipaparkan oleh alat elektronik dapat membahayakan kesehatan. Radiasi elektromagnetik diduga dapat diserap oleh Sansevieria sp. Penelitian ini bertujuan untuk mengetahui pengaruh Sansevieria spp. terhadap penurunan tingkat radiasi elektromagnetik. Jenis penelitian yang digunakan adalah pre experiment dengan rancangan one group pre test and post test design. Radiasi elektromagnetik diukur sebelum dan sesudah disandingkan dengan sansevieria dengan berbagai variasi jenis, posisi, dan jarak peletakkan dari sumber radiasi. Hasil diuji menggunakan Paired $t$ test dan Latin Square Anova. Hasil penelitian menunjukkan rata-rata tingkat radiasi elektromagnetik alat elektronik sebelum disandingkan dengan Sansevieria sp. adalah $3 \mathrm{~cm}=1101,48 \mu W / \mathrm{cm}^{2}, \quad 5 \mathrm{~cm}=914,53 \mu W / \mathrm{cm}^{2}, 7,5 \mathrm{~cm}=744,97 \mu W / \mathrm{cm}^{2}$, dan $10 \mathrm{~cm}=586,33 \mu W / \mathrm{cm}^{2}$ dan sesudah disandingkan dengan Sansevieria sp. adalah $3 \mathrm{~cm}=987,29 \mu \mathrm{W} / \mathrm{cm}^{2}, 5 \mathrm{~cm}=823,45 \mu \mathrm{W} / \mathrm{cm}^{2}$, $7,5 \mathrm{~cm}=695,55 \mu \mathrm{W} / \mathrm{cm}^{2}$, dan $10 \mathrm{~cm}=493,40 \mu W / \mathrm{cm}^{2}$. Uji Paired $t$ menunjukkan ada perbedaan tingkat radiasi elektromagnetik alat elektronik sebelum dan sesudah disandingkan dengan Sansevieria sp. $(p=0,000)$. Uji Latin Square Anova menunjukkan ada perbedaan penurunan antar jenis sansevieria $(p=0,001)$, posisi peletakkan Sansevieria $s p . \quad(p=0,000)$, dan jarak peletakkan Sansevieria $s p$. ( $p=0,003)$ yang memberikan pengaruh secara bersamaan sebesar 4,1\%. Simpulan penelitian ini adalah ada pengaruh Sansevieria sp. terhadap penurunan tingkat radiasi elektromagnetik dengan efektivitas sebesar 11,46\%. Peneliti menyarankan untuk dilakukan penelitian lebih lanjut dengan jenis dan jumlah daun atau rumpun, jarak, dan posisi peletakkan sansevieria yang berbeda.
\end{abstract}

Kata kunci: radiasi elektromagnetik dan sansevieria

\begin{abstract}
The Influence of Sansevieria spp. Towards The Decreasing of Electromagnetic Radiation Level in Laboratory of Environmental Health Department Purwokerto Year 2016. Electromagnetic radiation which is spread out by electronic devices can harm health. Electromagnetic radiation is presumed to be able to be absorbed by Sansevieria sp. The purpose of this research is to find out the influence of Sansevieria spp. towards the decreasing of electromagnetic radiation level. The type of research used in this research is pre experiment with one group pre-test and post-test design. Electronic radiation was measured before and after sansevieria were placed closely to radiation sources with variation of species, position, and distance. The result were tested by Paired t test and Latin Square Anova. The result of this research shows that average of electromagnetic radiation before Sansevieria sp. was placed closely to radiation sources were $3 \mathrm{~cm}=1101.48 \mu W / \mathrm{cm}^{2}, 5 \mathrm{~cm}=914.53 \mu W / \mathrm{cm}^{2}, 7.5 \mathrm{~cm}=$ $744.97 \mu W / \mathrm{cm}^{2}$, and $10 \mathrm{~cm}=586.33 \mu W / \mathrm{cm}^{2}$ and after were $3 \mathrm{~cm}=987.29 \mu W / \mathrm{cm}^{2}, 5 \mathrm{~cm}=$ $823.45 \mu \mathrm{W} / \mathrm{cm}^{2}, 7.5 \mathrm{~cm}=695.55 \mu \mathrm{W} / \mathrm{cm}^{2}$, and $10 \mathrm{~cm}=493.40 \mu \mathrm{W} / \mathrm{cm}^{2}$. Paired t test shows that there was a difference in electromagnetic radiation level of electronic devices before and after Sansevieria sp. was placed closely $(p=0.000)$. Latin Square Anova test shows that there was a difference in the decreasing between the types of Sansevieria $(p=0.001)$, the position of placing Sansevieria $s p .(p=0.000)$, and distance of placing Sansevieria sp. $(p=0.003)$ which gave influence at the same time that was $4.1 \%$. The conclusion of this research is that there was an influence of Sansevieria sp. towards the decreasing of electromagnetic radiation level with $11.46 \%$ of effectiveness. The researcher suggests doing further researches with other types and amount of leaves, distance, and position of placing different sansevieria.
\end{abstract}

Keywords: electromagnetic radiation and sansevieria

\footnotetext{
1) E-mail: retnopmoeljanie@gmail.com

2) E-mail: sugengzend@gmail.com

3) E-mail: yulianto_61@yahoo.com
} 


\section{Pendahuluan}

Saat ini manusia tidak bisa lepas dari teknologi. Kehadiran peralatan elektronik mempermudah semua aspek kehidupan dan semakin meluas di lingkungan masyarakat. Swamardika (2009) menyebutkan banyak kalangan mengklaim bahwa gelombang elektromagnetik yang dipancarkan oleh alat-alat listrik dapat mengganggu kesehatan pengguna dan orangorang yang berdiri di sekitarnya. Potensi gangguan kesehatan akibat radiasi elektromagnetik yang dikemukakan oleh WHO (1990) dan Ikatan Dokter Indonesia (1997) yaitu terhadap berbagai sistem tubuh seperti sistem darah, sistem kardiovaskular, sistem saraf, sistem reproduksi, sistem endokrin, dan hipersensitivitas yang menimbulkan berbagai gejala maupun keluhan penyakit (Anies, 2006).

Hasil penelitian Arif dkk. (2011) menunjukkan bahwa nilai efisiensi tumbuhan dalam meredam radiasi gelombang elektromagnetik sebesar $38 \%$. Sansevieria sp. atau lidah mertua merupakan tumbuhan yang dikenal sebagai tanaman antipolutan dan dapat mereduksi gelombang elektromagnetik. (Kompas, 2009). Tanaman ini diminati karena warna dan bentuknya menarik, mudah pemeliharaannya, dan bisa tumbuh dalam kondisi sedikit air dan cahaya matahari.

Penggunaan alat elektronik telah meluas, namun belum banyak dilakukan upaya untuk mengurangi radiasi elektromagnetik alat elektronik tersebut. Penelitian ini bertujuan untuk mengetahui pengaruh Sansevieria spp. terhadap penurunan tingkat radiasi elektromagnetik di Laboratorium Jurusan Kesehatan Lingkungan Purwokerto tahun 2016.

\section{Bahan dan Metode}

Variabel terikat dalam penelitian ini adalah tingkat radiasi elektromagnetik. Variabel bebas dalam penelitian ini adalah jenis, posisi, dan jarak peletakkan sansevieria. Variabel pengganggu dalam penelitian ini yaitu keberadaan benda-benda di ruangan.

Jenis penelitian yang digunakan adalah pre experiment dengan rancangan one group pre test and post test design. Alat elektronik yang diukur tingkat radiasinya adalah oven listrik Kirin, stereo Tens, monitor komputer Inforce, dan laptop Lenovo dalam keadaan dicharge. Pengukuran dilakukan pada jarak 3 $\mathrm{cm}, 5 \mathrm{~cm}, 7,5 \mathrm{~cm}$, dan $10 \mathrm{~cm}$ dari depan alat elektronik dengan pengambilan data hasil pembacaan angka maksimum dari pembacaan detektor.

Alat yang digunakan untuk mengukur tingkat radiasi elektromagnetik adalah detektor radiasi elektromagnetik DT-1130. Sansevieria yang digunakan adalah $S$. trifasciata 'Laurentii', $S$. masoniana Chahin., S. cylindrica Bojer ex. Hook, dan $S$. trifasciata 'Tiger Stripe' yang diletakkan di samping kanan, belakang, samping kiri, dan depan alat elektronik yang akan diukur radiasi elektromagnetiknya dengan jarak $30 \mathrm{~cm}, 50 \mathrm{~cm}, 75$ $\mathrm{cm}$ dan $100 \mathrm{~cm}$.
Data hasil penelitian ditabulasi lalu dihitung nilai mean dan proporsi untuk selanjutnya dideskripsikan. Analisis bivariat yang digunakan adalah paired $t$ test untuk membandingkan antara kondisi sebelum diberi perlakuan dengan kondisi setelah diberi perlakuan. Analisis multivariat yang digunakan adalah uji anova latin square untuk mengetahui pengaruh variasi perlakuan pada variabel dependen.

\section{Hasil dan Pembahasan}

Pengukuran tingkat radiasi elektromagnetik dilakukan di laboratorium fisika lingkungan dan sanitasi industri dan keselamatan kerja dengan volume ruangan $8,87 \mathrm{~m}$ x $6,88 \mathrm{~m}$ x 3,30 m. Pengukuran radiasi elektromagnetik dilakukan pada tanggal 21 dan 22 Mei 2016 pukul 09.00 - 19.00 WIB. Suhu ruangan $25-26^{\circ} \mathrm{C}$. Kelembaban ruangan $80-86 \%$. Pencahayaan yang digunakan adalah pencahayaan alami dan buatan. Pencahayaan alami sebesar 34-86 lux dan pencahayaan buatan sebesar 62,11-70,39 lux. Di dalam ruangan terdapat rak kaca yang berisi alat-alat pemeriksaan parameter lingkungan, peralatan K3, meja dan kursi untuk kegiatan perkuliahan, dan sumber radiasi elektromagnetik lain diantaranya lampu listrik yang menyala dan jaringan listrik yang aktif.

\section{Tingkat Radiasi Elektromagnetik berdasarkan Sumber Radiasi Elektromagnetik}

Pengukuran tingkat radiasi elektromagnetik dilakukan pada alat elektronik oven listrik, stereo, monitor komputer, dan laptop. Hasil menunjukkan rata-rata tingkat radiasi elektromagnetik alat elektronik sebelum disandingkan dengan Sansevieria sp. adalah oven listrik 1036,03 $\mu \mathrm{W} / \mathrm{cm}^{2}$, stereo 403,98 $\mu \mathrm{W} / \mathrm{cm}^{2}$, monitor komputer $1004,67 \mu \mathrm{W} / \mathrm{cm}^{2}$, dan laptop $902,64 \mu \mathrm{W} / \mathrm{cm}^{2}$. Rata-rata tingkat radiasi elektromagnetik alat elektronik sesudah disandingkan dengan Sansevieria sp. adalah oven listrik 982,76 $\mu \mathrm{W} / \mathrm{cm}^{2}$, stereo $304,14 \mu \mathrm{W} / \mathrm{cm}^{2}$, monitor komputer $901,88 \mu \mathrm{W} / \mathrm{cm}^{2}$, dan laptop $774,92 \mu \mathrm{W} / \mathrm{cm}^{2}$. Hasil pengukuran tersebut menunjukkan bahwa Sansevieria sp. mampu menurunkan tingkat radiasi elektromagnetik alat-alat elektronik tersebut. Rata-rata penurunan tingkat radiasi elektromagnetik setelah disandingkan dengan Sansevieria sp. sebesar 95,90 $\mu \mathrm{W} / \mathrm{cm}^{2}$, dengan efektivitas penurunan tertinggi terjadi pada stereo sebesar $24,71 \%$ dan terendah pada oven listrik, yaitu $5,14 \%$.

Efektivitas penurunan tingkat radiasi elektromagnetik yang berbeda dapat dikarenakan perbedaan rentang frekuensi alat elektronik. Gelombang elektromagnetik dan gelombang bunyi mempunyai persamaan pada sifat energinya, yaitu dapat dipantulkan, mengalami interferensi dan difraksi. Dalam gelombang bunyi, terdapat istilah koefisien absorpsi. Besarnya penyerapan bunyi suatu bahan pada frekuensi tertentu dinyatakan dengan koefisien absorpsi bunyi $(\alpha)$ (Tiastiti, 2012). Bahan absorbsi berfungsi diantaranya untuk menyerap 
gangguan yang tidak diinginkan dan menghilangkan rentang frekuensi tertentu.

Energi dalam radiasi elektromagnetik berupa foton berdasarkan partikelnya. Berdasarkan konstanta Planck, E = Hf, dimana E adalah energi foton, $\mathrm{h}$ ialah konstanta Planck $\left(6.626 \times 10^{-34} \mathrm{~J} \cdot \mathrm{s}\right)$ dan $\mathrm{f}$ adalah frekuensi gelombang. Nilai frekuensi sebanding dengan energi. Berdasarkan hal tersebut dapat dihubungkan antara fungsi bahan absorbsi dengan pengurangan radiasi elektromagnetik oleh sansevieria, yaitu sansevieria menghilangkan rentang frekuensi tertentu pada radiasi elektromagnetik yang dipancarkan oleh alat elektronik tersebut.

\section{Tingkat Radiasi Elektromagnetik berdasarkan Jarak Pengukuran}

Pengukuran tingkat radiasi elektromagnetik dilakukan pada jarak $3 \mathrm{~cm}, 5 \mathrm{~cm}, 7,5 \mathrm{~cm}$, dan $10 \mathrm{~cm}$ dari depan alat elektronik. Hasil menunjukkan ratarata tingkat radiasi elektromagnetik pada tiap jarak pengukuran sebelum disandingkan dengan Sansevieria

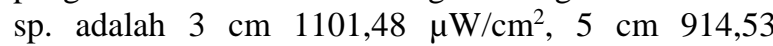

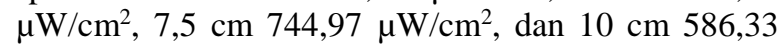
$\mu \mathrm{W} / \mathrm{cm}^{2}$. Rata-rata tingkat radiasi elektromagnetik alat elektronik sesudah disandingkan dengan Sansevieria

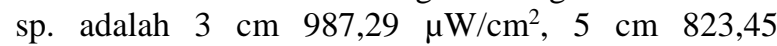
$\mu \mathrm{W} / \mathrm{cm}^{2}, 7,5 \mathrm{~cm} 659,55 \mu \mathrm{W} / \mathrm{cm}^{2}$, dan $10 \mathrm{~cm} \mathrm{493,40}$ $\mu \mathrm{W} / \mathrm{cm}^{2}$. Hasil pengukuran tersebut menunjukkan bahwa Sansevieria sp. mampu menurunkan tingkat radiasi elektromagnetik pada tiap jarak pengukuran dari alat elektronik tersebut.

Tabel 1. Hasil uji Paired $t$

\begin{tabular}{cccc}
\hline No. & $\begin{array}{c}\text { Jarak } \\
\text { Pengukuran }\end{array}$ & $\mathbf{p}$ & Interpretasi \\
\hline 1. & $3 \mathrm{~cm}$ & 0,000 & Ada Perbedaan \\
2. & $5 \mathrm{~cm}$ & 0,000 & Ada Perbedaan \\
3. & $7,5 \mathrm{~cm}$ & 0,000 & Ada Perbedaan \\
4. & $10 \mathrm{~cm}$ & 0,000 & Ada Perbedaan \\
5. & Total & 0,000 & Ada Perbedaan \\
\hline
\end{tabular}

Hasil uji Paired $t$ menunjukkan adanya perbedaan tingkat radiasi elektromagnetik yang dipancarkan alat elektronik antara sebelum dan sesudah disandingkan dengan Sansevieria sp. dengan nilai $\mathrm{p}=0,000$ yang berarti $<0,05$ sehingga $\mathrm{Ho}$ ditolak. Hasil tersebut menunjukkan bahwa ada pengaruh Sansevieria sp. terhadap penurunan tingkat radiasi elektromagnetik.
Tabel 2. Efektivitas Penurunan Tingkat Radiasi Elektromagnetik Setelah Disandingkan dengan Sansevieria sp.

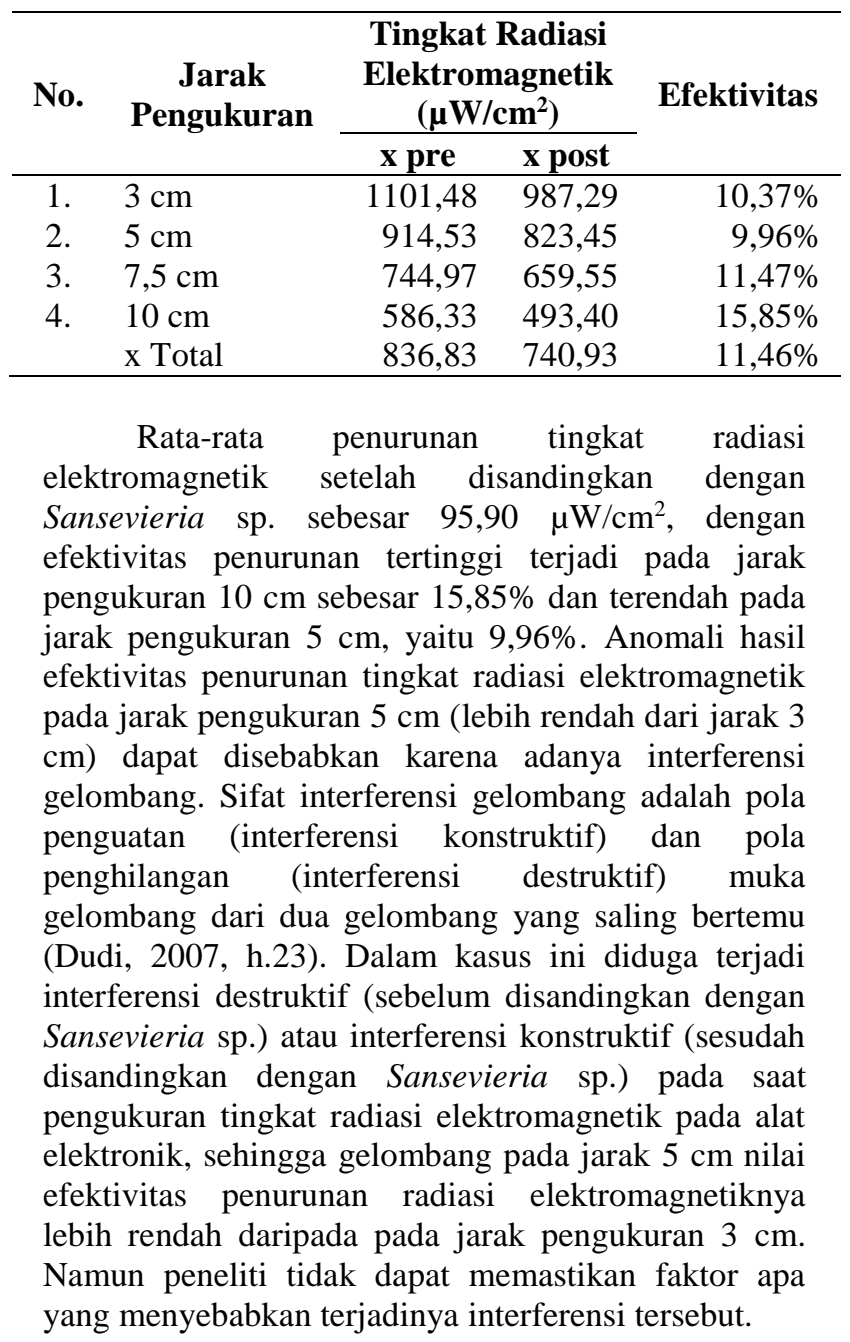

\section{Pengaruh Sansevieria sp. terhadap Penurunan Tingkat Radiasi Elektromagnetik}

Penurunan tingkat radiasi elektromagnetik setelah disandingkan dengan Sansevieria sp. diuji menggunakan Latin Square Anova dengan hasil sebagai berikut.

Tabel 3. Hasil uji Latin Square Anova

\begin{tabular}{|c|c|c|c|}
\hline No. & $\begin{array}{c}\text { Variable } \\
\text { Independen }\end{array}$ & Sig. & Interpretasi \\
\hline 1. & Jenis sansevieria & 0,001 & Ada pengaruh \\
\hline 2. & $\begin{array}{l}\text { Posisi peletakan } \\
\text { Sansevieria }\end{array}$ & 0,000 & Ada pengaruh \\
\hline 3. & $\begin{array}{l}\text { Jarak peletakan } \\
\text { sansevieria }\end{array}$ & 0,003 & Ada pengaruh \\
\hline
\end{tabular}


Jenis, posisi, dan jarak peletakan sansevieria memberikan pengaruh secara bersamaan terhadap penurunan tingkat radiasi elektromagnetik sebesar $4,1 \%$. Jenis sansevieria memberikan pengaruh yang bermakna terhadap penurunan tingkat radiasi elektromagnetik, dilihat dari nilai signifikansinya dimana $\mathrm{p}=0,001<\alpha(0,05)$. Demikian pula dengan posisi dan jarak peletakan Sansevieria sp. juga memberikan pengaruh pada penurunan tingkat radiasi elektromagnetik karena nilai signifikansinya $\mathrm{p}=0,000$ dan $\mathrm{p}=0,003$, dimana nilai $\mathrm{p}<\alpha(0,05)$. Setelah diketahui semua variable bebas berpengaruh terhadap penurunan tingkat radiasi elektromagnetik, maka perlu uji lanjut untuk mengetahui perbedaan antar kelompok pada variable bebas dengan Least Significant Defference - test (LSD).

\section{Jenis Sansevieria}

Tabel 4 : Hasil Uji Lanjut Jenis Sansevieria

\begin{tabular}{|c|c|c|c|}
\hline No & $\begin{array}{c}\text { Perbandingan } \\
\text { Jenis } \\
\text { Sansevieria } \\
\end{array}$ & $\begin{array}{c}\text { Mean } \\
\text { difference }\end{array}$ & $\begin{array}{c}\text { Nilai p } \\
\text { (sig) }\end{array}$ \\
\hline 1. & $\begin{array}{l}\text { S. trifasciata } \\
\text { Laurentii': } \\
\text { S. masoniana } \\
\text { Chahin. }\end{array}$ & 45,145 & 0,002 \\
\hline 2. & $\begin{array}{l}\text { S. trifasciata } \\
\text { 'Laurentii' : } \\
\text { S. cylindrica } \\
\text { Bojer ex. } \\
\text { Hook }\end{array}$ & 46,941 & 0,001 \\
\hline 3. & $\begin{array}{l}\text { S. trifasciata } \\
\text { 'Laurentii': } \\
\text { S. trifasciata' } \\
\text { Tiger Stripe' }\end{array}$ & 49,563 & 0,001 \\
\hline
\end{tabular}

Pada hasil uji lanjut dapat dilihat bahwa terdapat perbedaan antara tingkat radiasi elektromagnetik setelah disandingkan dengan $S$. trifasciata 'Laurentii' dan S. masoniana Chahin. Hal tersebut dapat dilihat pada nilai $\mathrm{p}=0,002<0,05$, berarti kedua jenis sansevieria tersebut berbeda dalam menurunkan tingkat radiasi elektromagnetik. Hasil yang sama juga dapat diihat pada perbandingan $S$. trifasciata 'Laurentii' dengan S. cylindrica Bojer ex. Hook dan $S$. trifasciata 'Tiger Stripe', yaitu nilai $\mathrm{p}=0,001<0,05$, berarti kedua jenis sansevieria tersebut berbeda penurunan tingkat radiasi elektromagnetiknya. Efektivitas berbagai jenis sansevieria dalam menurunkan radiasi elektromagnetik tersebut dapat diketahui melalui perhitungan persentase efektivitas yang disajikan dalam Gambar 1.

\section{Persentase Efektivitas Penurunan Tingkat Radiasi Elektromagnetik berdasarkan Jenis Sansevieria}

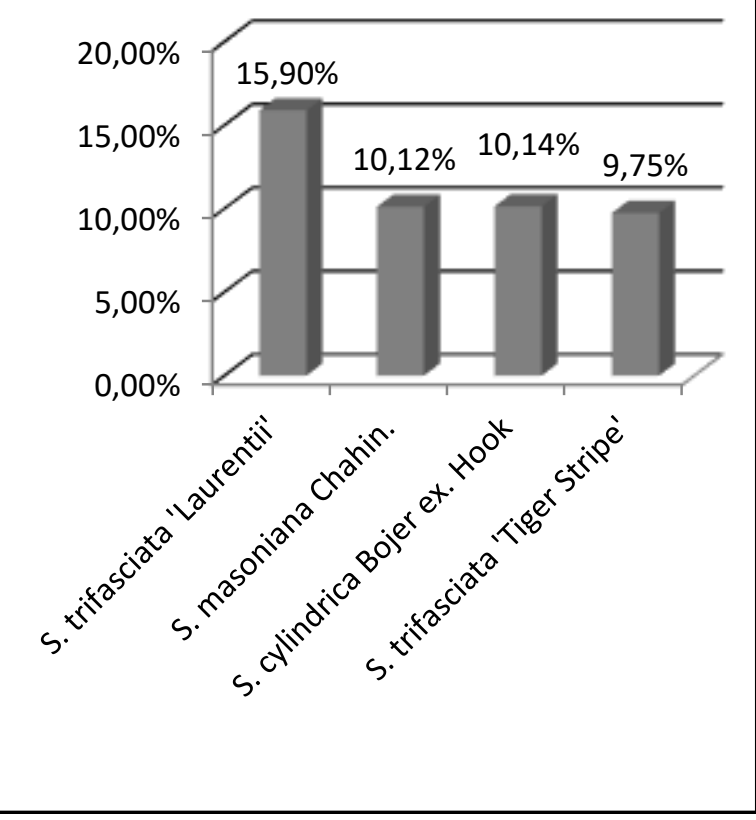

Gambar 1. Grafik Persentase Efektivitas Penurunan Tingkat Radiasi Elektromagnetik berdasarkan Jenis Sansevieria

Berdasarkan hasil perhitungan efektivitas penurunan tingkat radiasi elektromagnetik setelah disandingkan dengan keempat jenis sansevieria, $S$. trifasciata 'Laurentii' memiliki nilai efektivitas yang paling tinggi yaitu sebesar $15,90 \%$. Sansevieria jenis lain yaitu $S$. masoniana Chahin. memiliki nilai efektivitas dalam menurunkan tingkat radiasi elektromagnetik sebesar 10,12\%, S. cylindrica Bojer ex. Hook sebesar 10,14\%, dan S. trifasciata 'Tiger Stripe' sebesar 9,75\%.

Sebuah riset menyebutkan bahwa satu helai daun Sansivera mampu menyerap formaldehid sebanyak, 0,938 mg per jam. Adapun untuk ruangan seluas $100 \mathrm{~m}$ persegi cukup ditempatkan jenis S.trifasciata 'Laurentii' dewasa berdaun 5 helai agar ruangan itu bebas polutan. (Anonim, 2014) Hal tersebut dapat menjadi pendukung bahwa $S$. trifasciata 'Laurentii' mampu dalam menurunkan polusi udara di dalam ruangan, termasuk radiasi elektromagnetik. Berdasarkan hasil perhitungan efektivitas $S$. trifasciata 'Laurentii' memiliki nilai efektivitas yang paling tinggi yaitu sebesar $15,89 \%$, yang berarti sansevieria tersebut paling efektif dalam menurunkan tingkat radiasi elektromagnetik diantara ketiga sansevieria lainnya. 
Posisi Peletakan Sansevieria sp.

Tabel 5. Hasil Uji Lanjut Posisi Peletakan Sansevieria

\begin{tabular}{clcc}
\hline No. & $\begin{array}{l}\text { Perbandingan } \\
\text { Posisi Peletakan } \\
\text { Sansevieria }\end{array}$ & $\begin{array}{c}\text { Mean } \\
\text { difference }\end{array}$ & $\begin{array}{c}\text { Nilai p } \\
\text { (sig) }\end{array}$ \\
\hline 1. & $\begin{array}{l}\text { Belakang : } \\
\text { Samping Kiri } \\
\text { Belakang : }\end{array}$ & 42.547 & 0.003 \\
2. & $\begin{array}{l}\text { Samping Kanan } \\
\text { Belakang : }\end{array}$ & 63.434 & 0.000 \\
3. & Depan & 49.621 & 0.001 \\
\hline
\end{tabular}

Pada hasil uji lanjut dapat dilihat bahwa terdapat perbedaan antara tingkat radiasi elektromagnetik setelah disandingkan dengan posisi peletakan sansevieria di belakang dan samping kiri sumber radiasi. Hal tersebut dapat dilihat pada nilai $\mathrm{p}=0,003<0,05$, berarti kedua posisi peletakan sansevieria tersebut berbeda dalam menurunkan tingkat radiasi elektromagnetik. Hasil yang sama juga dapat diihat pada perbandingan posisi peletakan di belakang dengan di samping kanan dan depan sumber radiasi, yaitu nilai $\mathrm{p}=0,000$ dan $\mathrm{p}=0,001<0,05$, berarti kedua posisi peletakan sansevieria tersebut berbeda penurunan tingkat radiasi elektromagnetiknya. Efektivitas jenis sansevieria dalam menurunkan tingkat radiasi elektromagnetik dapat dilihat pada Gambar 2.

\section{Persentase Efektivitas Penurunan Tingkat Radiasi Elektromagnetik berdasarkan Posisi Peletakkan Sansevieria}

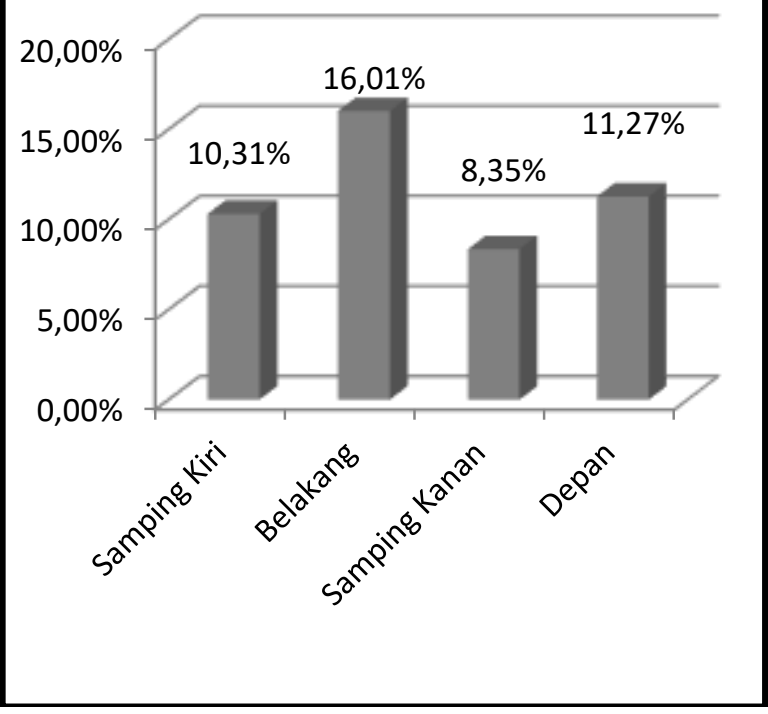

Gambar 2. Grafik Persentase Efektivitas Penurunan Tingkat Radiasi Elektromagnetik berdasarkan Posisi Peletakan Sansevieria
Hasil perhitungan efektivitas penurunan tingkat radiasi setelah disandingkan dengan sansevieria menurut posisi sansevieria dari sumber radiasi yaitu peletakan sansevieria di samping kiri menurunkan $10,31 \%$, peletakan di belakang sebesar $16,01 \%$, peletakan di samping kanan $8,35 \%$, dan peletakan di depan sebesar $11,27 \%$. Peletakan sansevieria yang paling efektif dalam menurunkan tingkat radiasi elektromagnetik dari keempat posisi sansevieria adalah pada posisi belakang sumber radiasi elektromagnetik, yaitu sebesar $16,01 \%$.

Posisi peletakan sansevieria di belakang sumber radiasi memiliki nilai efektivitas yang paling tinggi yaitu sebesar $16,01 \%$, yang berarti posisi tersebut paling efektif dalam menurunkan tingkat radiasi elektromagnetik diantara ketiga posisi peletakan sansevieria lainnya. Posisi peletakan Sansevieria sp. dibelakang alat elektronik memiliki nilai efektivitas yang paling tinggi diduga adanya kontribusi bahan penyerap lain pada saat Sansevieria sp. diletakkan pada posisi tersebut. Namun peneliti tidak dapat memastikan bahan apa yang dapat mempengaruhi penyerapan radiasi elektromagnetik tersebut.

\section{Jarak Peletakan Sansevieria sp.}

Tabel 6. Hasil Uji Lanjut Jarak Peletakan Sansevieria

\begin{tabular}{ccrc}
\hline No. & $\begin{array}{c}\text { Perbandingan } \\
\text { Jarak Peletakan } \\
\text { Sansevieria }\end{array}$ & $\begin{array}{c}\text { Mean } \\
\text { difference }\end{array}$ & $\begin{array}{c}\text { Nilai p } \\
\text { (sig) }\end{array}$ \\
\hline 1. & $30 \mathrm{~cm}: 75 \mathrm{~cm}$ & 47.363 & 0.001 \\
2. & $50 \mathrm{~cm}: 75 \mathrm{~cm}$ & 43.719 & 0.002 \\
\hline
\end{tabular}

Pada hasil uji lanjut dapat dilihat bahwa terdapat perbedaan antara tingkat radiasi elektromagnetik setelah disandingkan dengan sansevieria menurut jarak peletakan $30 \mathrm{~cm}$ dengan 75 $\mathrm{cm}$ dari sumber radiasi elektromagnetik. Hal tersebut dapat dilihat pada nilai $\mathrm{p}=0,001<0,05$, berarti kedua jarak peletakan sansevieria tersebut berbeda dalam menurunkan tingkat radiasi elektromagnetik. Hasil yang sama juga dapat diihat pada perbandingan jarak peletakan sansevieria $50 \mathrm{~cm}$ dengan $75 \mathrm{~cm}$, yaitu nilai $\mathrm{p}=0,002<0,05$, berarti kedua jarak peletakan sansevieria tersebut berbeda penurunan tingkat radiasi elektromagnetiknya. Efektivitas berbagai jarak peletakan sansevieria dalam menurunkan radiasi elektromagnetik tersebut dapat diketahui melalui perhitungan persentase efektivitas. Efektivitas jarak peletakan sansevieria dalam menurunkan tingkat radiasi elektromagnetik dapat dilihat pada Gambar 3. 


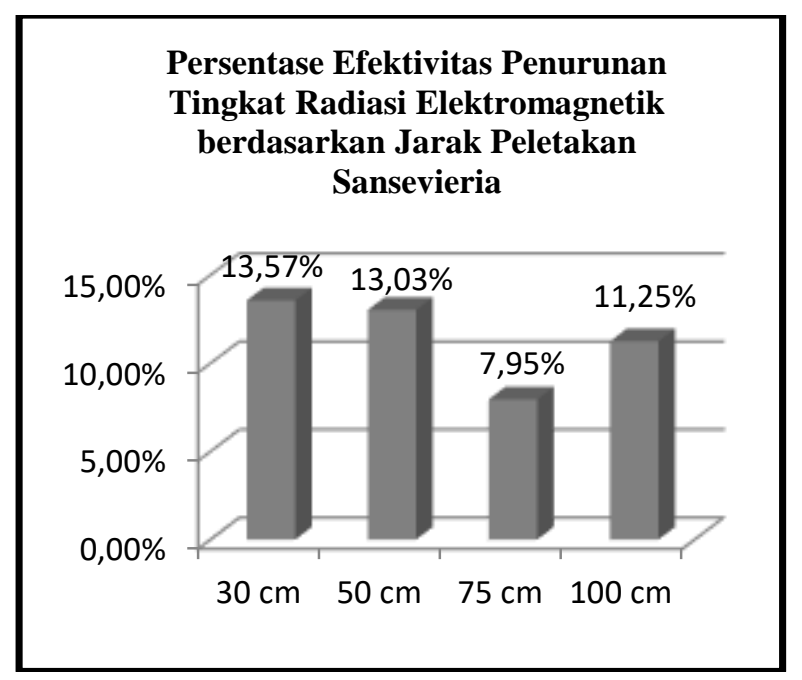

Gambar 3. Grafik Persentase Efektivitas Penurunan Tingkat Radiasi Elektromagnetik berdasarkan Jarak Peletakan Sansevieria

Hasil perhitungan efektivitas sansevieria dalam menurunkan tingkat radiasi menurut jarak sansevieria dari sumber radiasi yaitu adalah jarak $30 \mathrm{~cm}$ sebesar $13,57 \%$, jarak $50 \mathrm{~cm}$ sebesar $13,03 \%$, jarak $75 \mathrm{~cm}$ sebesar $7,95 \%$, dan jarak $100 \mathrm{~cm}$ sebesar $11,25 \%$. Berdasarkan hasil perhitungan efektivitas, jarak peletakan sansevieria $30 \mathrm{~cm}$ dari sumber radiasi memiliki nilai efektivitas yang paling tinggi yaitu sebesar $13,57 \%$, sedangkan nilai efektivitas penurunan tingkat radiasi elektromagnetik paling rendah adalah pada jarak peletakan $75 \mathrm{~cm}$, yaitu sebesar 7,95\%. Meskipun demikian, secara statistik tidak ada perbedaan penurunan tingkat radiasi antara peletakan sansevieria pada jarak $75 \mathrm{~cm}$ dengan $100 \mathrm{~cm}$. Anomali hasil efektivitas penurunan tingkat radiasi elektromagnetik pada jarak peletakan Sansevieria sp. $75 \mathrm{~cm}$ yang lebih lebih rendah dari jarak $100 \mathrm{~cm}$ dapat disebabkan karena adanya interferensi gelombang. Dalam kasus ini diduga terjadi interferensi destruktif pada saat pengukuran tingkat radiasi elektromagnetik pada alat elektronik yang diberi perlakuan peletakan Sansevieria sp. pada jarak $75 \mathrm{~cm}$ sehingga tingkat radiasi elektromagnetik maupun nilai efektivitas penurunan radiasi elektromagnetiknya lebih sedikit daripada pada jarak peletakan $100 \mathrm{~cm}$.

\section{Simpulan dan Saran Simpulan}

Rata-rata tingkat radiasi elektromagnetik sebelum disandingkan dengan Sansevieria spp. adalah jarak pengukuran $3 \mathrm{~cm}: 1101,48 \mu \mathrm{W} / \mathrm{cm}^{2}$, jarak pengukuran $5 \mathrm{~cm}$ : $914,53 \mu \mathrm{W} / \mathrm{cm}^{2}$, jarak pengukuran $7,5 \mathrm{~cm}: 744,97 \mu \mathrm{W} / \mathrm{cm}^{2}$, dan jarak pengukuran $10 \mathrm{~cm}$ : $586,33 \mu \mathrm{W} / \mathrm{cm}^{2}$.

Rata-rata tingkat radiasi elektromagnetik sesudah disandingkan dengan Sansevieria spp. adalah jarak pengukuran $3 \mathrm{~cm}$ : 987,29 $\mu \mathrm{W} / \mathrm{cm}^{2}$, jarak pengukuran $5 \mathrm{~cm}: 823,45 \mu \mathrm{W} / \mathrm{cm}^{2}$, jarak pengukuran $7,5 \mathrm{~cm}: 659,55 \mu \mathrm{W} / \mathrm{cm}^{2}$, dan jarak pengukuran $10 \mathrm{~cm}$ : $493,4023 \mu \mathrm{W} / \mathrm{cm}^{2}$.
Ada pengaruh Sansevieria spp. terhadap penurunan tingkat radiasi elektromagnetik. Jenis sansevieria yang paling tinggi efektivitasnya dalam menurunkan tingkat radiasi elektromagnetik adalah $S$. trifasciata 'Laurentii', yaitu sebesar 15,89\%. Posisi peletakan sansevieria yang paling tinggi efektivitasnya dalam menurunkan tingkat radiasi elektromagnetik adalah di belakang sumber radiasi, yaitu sebesar $16,01 \%$. Peletakan sansevieria yang paling efektif dalam menurunkan tingkat radiasi elektromagnetik adalah pada jarak $30 \mathrm{~cm}$ yaitu sebesar $13,57 \%$.

Rata-rata tingkat radiasi elektromagnetik alat elektronik setelah disandingkan dengan Sansevieria sp. adalah sebesar $1,77 \times 10^{-4} \mathrm{mT}\left(740,93 \mu \mathrm{W} / \mathrm{cm}^{2}\right)$ masih memenuhi standar batas pajanan WHO dan IRPA (medan listrik dan medan magnet pada lingkungan umum maksimal $0,1 \mathrm{mT}$ sampai 24 jam/hari dan $1 \mathrm{mT}$ untuk pajanan beberapa jam sehari) dan Permenakertrans No 13/MEN/X/2011 (maksimal $2 \mathrm{~T}$ pemaparan pada seluruh tubuh pada tempat kerja umum).

\section{Saran}

Perlu penelitian lebih lanjut dengan variabel titik pengukuran, jenis, jumlah daun atau rumpun, dan peletakkan sansevieria dengan variasi yang berbeda.

\section{Ucapan Terimakasih}

Terima kasih disampaikan kepada Jurusan Kesehatan Lingkungan Politeknik Kesehatan Kemenkes Semarang sehingga penelitian dapat terselesaikan.

\section{Daftar Pustaka}

Agromedia, 2007, Buku Pintar Tanaman Hias, Jakarta: Agromedia Pustaka

Ainie Khuriati, Eko Komaruddin, dan Muhammad Nur, 2006, Disain Peredam Suara Berbahan Dasar Sabut Kelapa dan Pengukuran Koefisien Penyerapan Bunyinya, Jurnal Berkala Fisika. Vol. 9 No. 1 Januari 2006: 1410-9662, at https://core.ac.uk/download/files/379/11703375 .$p d f$

Anies, 2006, SUTET: Potensi Gangguan Kesehatan Akibat Radiasi Elektromagnetik SUTET, Jakarta: PT Elex Media Komputindo

Anonim, 2011, Super-Wide Sansevieria, Mason's Congo Leaf Sanseveria, at http://www. almostedenplants.com/shopping/html/p652Supe rWideSansevieria\%20MasonsCongoLeafSanse veria.htm

, 2014, Sansevieria, Tanaman Hias Penyerap Polusi Paling Efektif, at http://www.uriflorist. com/sansevieria-tanaman-hias-penyerappolusi-paling-efektif

Arif Ismul Hadi, Rida Samdara dan Hesna Nurliana, 2011, Efisiensi Tumbuhan dalam Meredam Gelombang Elektromagnetik (Studi Kasus di SUTT Kota Bengkulu), Jurnal Gradien. Vol. 8 No. 12 Januari 2012: 722-727, at http:// 
ejournal.unib.ac.id/index.php/gradien/article/do wnload $/ 236 / 208$

Batan, 2016, Apa yang dimaksud dengan radiasi?, at http://www.batan.go.id/pusdiklat/elearning/prot eksiradiasi/pengenalan radiasi/1-1.htm

Bernardinus dan Wiryanta, 2007, Media Tanam Untuk Tanaman Hias, Jakarta: Agro Media Pustaka

Deni Listi Yanti, 2015, Pengaruh Orgonite terhadap Tingkat Radiasi Elektromangnetik di Laboratorium Kampus VII Kesehatan Lingkungan Purwokerto, Karya Tulis Ilmiah, Tidak dipublikasikan, Purwokerto: Poltekkes Kemenkes Semarang

Djamaluddin Ramlan dan Maisye Marlyn Kuhu, 2013, Petunjuk Praktis: Penulisan Penelitian Eksplanatif, Purwokerto: Universitas Jenderal Soedirman

Dudi Indrajit, 2007, Mudah dan Aktif Belajar Fisika untuk Kelas XII SMA/MA Program Ilmu Pengetahuan Alam, Bandung: Setia Purna Inves

EMC, 2015, at http://www.compeng.com.au/emc conversion tables field strength calculator .aspx

Germanstar, 2011, Shade-loving Xerics?, at http:// cactiguide.com/forum/viewtopic.php? $\mathrm{f}=12 \& \mathrm{t}=2$ 0499

Glaser, ZR, 2009, Organization and Management of a Non-ionizing Safety Program, Seminar Nasional, Jakarta

Heru Subaris dan Haryono, 2007, Hygiene Lingkungan Kerja, Jogjakarta: Mitra Cendikia Press

Jerusalemcherry, 2008, Bird's Nest Snake Plant, Good Luck Plant 'Hahnii' (Sansevieria trifasciata), at

http://davesgarden.com/guide/pf/showimage/17 $659 /$

Kompas, 2009, Ragam Manfaat Si Lidah Mertua, at http://properti.kompas.com/read/2009/04/22/21 391077/ragam.manfaat.si.lidah.mertua

Merry Wahyuningsih, 2011, Tanaman yang Sehat untuk di Dalam Rumah, at http://health. detik.com/read/2010/12/27/115115/1533247/76 6/tanaman-yang-sehat-untuk-di-dalam-rumah

Palmbob, 2006, Sansevieria 'Bantel's Sensation' (Sansevieria), at http://davesgarden.com/guides /pf/showimage/117066/

Ridley, John, 2006, Health \& Safety in Brief, Third Edition, Jakarta: Erlangga

Sentot Pramono, 2008, Pesona Sansevieria, Jakarta: Agromedia Pustaka
Soeripto M, 2008, Higiene Industri, Jakarta: FKUI

Sunardi dan Kartika Sari, 2012, Pengaruh Konsentrasi Larutan Ekstrak Daun Lidah Mertua terhadap Absorbansi dan Transmitansi pada Lapisan Tipis. Seminar Nasional Fisika, Jakarta, at http://www.snf-unj.ac.id/index.php/download file/view/27/160/

Surip Prayugo, 2008, Galeri Sansevieria : Dilengkapi Cara Memilih, Merawat, dan Memperbanyak, Depok: Penebar Swadaya

Swamardika, I. B. Alit, 2009, Pengaruh Radiasi Gelombang Elektromagnetik Terhadap Kesehatan Manusia (Suatu Kajian Pustaka). Teknologi Elektro. Vol. 8 No.1: hal 106-109, at http://download.portalgaruda.org/article.php?art $\underline{\text { icle }}=15306 \& \mathrm{val}=985$

Sylvia Soeng, Teresa Liliana Wargasetia, dan Anna Steven, 2007, Efek Gelombang Elektromagnetik Telepon Seluler terhadap Spermatozoa Mencit Galur BALB/C, Jurnal Kedoktean Maranatha. Vol. 7 No. 1 Juli 2007: 26-35, at http://perpus. org/doc/6d-efek-gelombang-elektromagnetiktelepon-s.html

Tahir, M. Idariani dan Maloedyn Sitanggang, 2008, 165 Sansevieria Eksklusif, Jakarta: AgroMedia Pustaka

Trelia Boel, 2009, Dental radiologi: Prinsip dan Teknik, Medan: USU Press

Trubus, 2008, Sansevieria: 200 Jenis Spektakuler; 400 Foto, Jakarta: Trubus Swadaya

Viva, 2015, Cegah Radiasi Alat Elektronik dengan 5 Tanaman ini, at http://log.viva.co.id/frame/read /aHR0cDovL3d3dy5hcmJhbWVkaWEuY29tLz IwMTUvMTIvY2FyYS1tZW5jZWdhaC1yYW RpYXNpLWFsYXQtZWxla3Ryb25pay5odG1 $\underline{\mathrm{s}}$

_ Tangkal Radiasi Laptop dan Komputer dengan Tanaman ini, at http://log.viva.co.id/ frame/read/aHR0cDovL2plbmRlbGFzZWhhdH EuYmxvZ3Nwb3QuY28uaWQvMjAxNS8xMi 90YW5na2FsLXJhZGlhc2ktbGFwdG9wLWR hbi1rb21wdXRlci5odG1s

Waugh, Jim, 2010, Living Safely with Electromagnetic Radiation, Teacher Newsmagazine Volume 23, Number 3, Nov./Dec. 2010, at http://bctf.ca/ publications/ NewsmagArticle.aspx?id=21792 